\title{
A Macroarray System for the Detection of Fungal and Oomycete Pathogens of Solanaceous Crops
}

\author{
Ning Zhang, Department of Plant Pathology and Plant-Microbe Biology, Cornell University, Geneva, NY 14456; \\ Meaghan L. McCarthy, Department of Biology, Hobart and William Smith Colleges, Geneva, NY 14456; and \\ Christine D. Smart, Department of Plant Pathology and Plant-Microbe Biology, Cornell University, Geneva
}

\begin{abstract}
Zhang, N., McCarthy, M. L., and Smart, C. D. 2008. A macroarray system for the detection of fungal and oomycete pathogens of solanaceous crops. Plant Dis. 92:953-960.

There are numerous fungal and oomycete pathogens that cause severe damage to solanaceous crops. Rapid and accurate detection and identification of these pathogens is critical for plant disease management. Recently, DNA array technology has been successfully applied for simultaneous detection of multiple microorganisms from various habitats. The goal of this project was to develop a multiplex detection and identification system for major fungal and oomycete pathogens of solanaceous crops. To facilitate this goal, we used a membrane-based macroarray technology that included at least two specific oligonucleotides per pathogen. Based on the internal transcribed spacer sequences of the rRNA genes, 105 oligonucleotides (17 to 27 bases long) specific for 25 pathogens of solanaceous crops were designed and spotted on a nylon membrane. The array was tested against the 25 target pathogen species, 46 infected field samples, and a number of nontarget species. Our results indicate that the oligonucleotide-based macroarray detection system is a reliable and effective method for pathogen detection and identification even when multiple pathogens are present in a field sample.
\end{abstract}

Additional keywords: microarray, molecular diagnostic, sensitivity, specificity

Fungi and oomycetes constitute the majority of pathogens that afflict members of the Solanaceae $(10,20)$. Early and accurate pathogen detection, identification, and quantification are essential for disease management for these economically important crops. In some cases, visible signs of the pathogen, such as sporulation, sclerotia, or mycelia, are present on the plant, enabling a rapid diagnosis. Although the pathogen frequently can be identified to the genus level quite quickly, identification to the species level can be difficult. Additionally, when multiple pathogens are present in a single sample, it can be difficult to detect and identify all species. To overcome these difficulties encountered when using traditional diagnostic methods, many researchers have chosen molecular diagnosis by DNA array technology. This technology can be used to detect and identify multiple pathogens simultaneously to species and infraspecies levels with highly specific detector oligonucleotides $(3,15$, 16,28).

First developed in the medical field in the late 1980s and early 1990s (11,17),

Corresponding author: C. D. Smart

E-mail: cds14@cornell.edu

Accepted for publication 18 February 2008.

doi:10.1094/PDIS-92-6-0953

(C) 2008 The American Phytopathological Society
DNA arrays have been applied and adapted to detection and identification of pathogenic and environmental microorganisms from various sources, including food, soil, animals, and agricultural crops $(1,6,13,16)$. In this technology, detector oligonucleotides hybridize with homologous amplified prelabeled (with a fluorescent dye, a chemiluminescence reporter, or a radioactive isotope) target DNA or RNA, which can then be detected. In general, two types of array platforms have been developed: the glass slide (microarray) and the nylon or nitrocellulose membrane (macroarray). The microarray enables higher oligonucleotide density where thousands of detector oligonucleotides can be spotted on a single slide. Therefore, one microarray is capable of detecting hundreds of different pathogens (3); however, each array can be used only once. Thus, the high cost and lower sensitivity associated with microarray production and result reading limit its application $(1,7,13,16)$. Membrane-based macroarrays require only a pin-tool for array production. Although it has lower throughput than a microarray, a 96-well microtiter plate-size membrane is still able to contain over 1,000 different detector oligonucleotides, and each array can be washed and reused many times. This capacity is much greater than other molecular diagnostic methods such as real-time polymerase chain reaction (PCR) and enzyme-linked immunosorbent assay $(2,3)$. Due to its relatively low cost and high throughput, the macroarray has been employed by many researchers for plant disease diagnostic in recent years $(1,7,13,16)$.

A number of macroarrays have been developed for detection and identification of fungal and oomycete pathogens in agriculture. These detection systems were proved to be both accurate and sensitive $(13,15,28)$. One of the most comprehensive DNA arrays is able to detect over a hundred Pythium spp. (21). However, most of the macroarray studies published to date contained small numbers of detector oligonucleotides for the detection of a specific group of pathogens. For example, a tomato vascular wilt pathogen detection array included three controls and 10 oligonucleotides specific for five taxa (three species and two genera; 13), and an apple disease detection array contained five controls and 21 oligonucleotides specific for seven fungal taxa and one bacterial target (18). The high-throughput potential of the array detection is far from being reached.

The goal of this project was to develop a detection and identification system for major fungal and oomycete pathogens of solanaceous crops. To facilitate this goal, we used macroarray technology, including at least two specific oligonucleotides per pathogen for 30 pathogens. The array was tested against pure cultures as well as more than 40 field and greenhouse samples. Our results showed that the macroarray is a reliable method for pathogen detection and identification even when multiple pathogens are present in a field sample.

\section{MATERIALS AND METHODS}

Microorganisms. Microorganisms used in this study are listed in Table 1. Spores of Spongospora subterranea f. sp. subterranea and Oidium neolycopersici were scraped directly from the host tissue. Phytophthora infestans isolates were cultured on rye B agar (4). All other isolates were grown on potato dextrose agar. All cultures were incubated at $24^{\circ} \mathrm{C}$ in cycle of $12 \mathrm{~h}$ of light and $12 \mathrm{~h}$ of darkness for 5 to 7 days before DNA extraction. For preservation, fungal cultures were maintained in $10 \%$ glycerol at $-80^{\circ} \mathrm{C}$; oomycetes were kept in distilled water at room temperature.

Field and greenhouse samples. During the years 2004 to 2006, 46 diseased solanaceous plant samples were collected from commercial production fields, research fields, and a research greenhouse 
and tested against the macroarray. Of the 46 samples, 24 were from tomato (Solanum lycopersicum), 10 each were from potato (S. tuberosum) and pepper (Capsicum annuum), and 2 were from eggplant ( $S$. melongea). The diseased part (root, stem, leaf, or fruit) of each sample was divided into three portions. The first portion was incubated in a moist chamber at $24^{\circ} \mathrm{C}$ for 3 to 7 days. Fungi and oomycetes that formed spores, sclerotia, or hyphal mass in the moist chamber were isolated

Table 1. Name, source, and host of the studied species ${ }^{\mathrm{a}}$

\begin{tabular}{|c|c|c|c|}
\hline Taxonomy, species & Isolate $^{b}$ & Host & Origin \\
\hline \multicolumn{4}{|l|}{ Fungi, Ascomycota } \\
\hline Alternaria alternata & 0495 & Solanum melongena & New York \\
\hline A. alternata & BMP0269, B. Pryor & NA & NA \\
\hline A. brassicae & BMP0323, B. Pryor & NA & NA \\
\hline A. infectoria & BMP0036, B. Pryor & NA & NA \\
\hline A. longissima & BMP0339, B. Pryor & NA & NA \\
\hline A. solani & BMP0182, B. Pryor & NA & NA \\
\hline A. solani & 2.25, T. Zitter & S. lycopersicum & New York \\
\hline Botrytis cinerea & 06105 & S. melongena & New York \\
\hline B. cinerea & B27, G. Abawi & Brassica oleracea & New York \\
\hline \multicolumn{2}{|c|}{ Cladosporium cladosporioides 0653-3 } & S. tuberosum & New York \\
\hline C. cladosporioides & $0664-2$ & Capsicum аппиит & New York \\
\hline C. fulvum & 0728 & S. lycopersicum & New York \\
\hline Colletotrichum coccodes & COL6, T. Zitter & S. tuberosum & New York \\
\hline \multicolumn{2}{|l|}{ C. coccodes } & C. аппиит & New York \\
\hline \multicolumn{2}{|l|}{ C. gloeosporioides } & S. lycopersicum & Georgia \\
\hline \multicolumn{2}{|l|}{ Corynespora cassiicola } & S. lycopersicum & Florida \\
\hline \multicolumn{2}{|l|}{ C. cassiicola } & S. lycopersicum & Guam \\
\hline \multicolumn{2}{|l|}{ Erysiphe necator } & Vitis vinifera & New York \\
\hline \multicolumn{2}{|l|}{ Fusarium cuneirostrum } & Phaseolus vulgaris & United States \\
\hline \multicolumn{2}{|l|}{ F. equiseti } & S. lycopersicum & New York \\
\hline \multicolumn{2}{|l|}{ F. graminearum } & S. tuberosum & New York \\
\hline \multicolumn{2}{|l|}{ F. illudens } & Beischmiedia tawa & New Zealand \\
\hline \multicolumn{2}{|l|}{ F. oxysporum } & S. lycopersicum & New York \\
\hline \multicolumn{2}{|l|}{ F. oxysporum } & S. lycopersicum & New York \\
\hline \multicolumn{2}{|l|}{ F. sambucinum } & S. tuberosum & Canada \\
\hline F. sambucinum & ATCC44651 & S. tuberosum & Idaho \\
\hline F. solanic & 0552 & С. аппиит & New York \\
\hline \multicolumn{2}{|l|}{ F. solani } & S. tuberosum & New York \\
\hline F. sporotrichioides & 05-15500, S. Jensen-Tracey & Cucurbita sp. & New York \\
\hline F. sporotrichioides & 05-15755C1, S. Jensen-Tracey & Chrysanthemum sp. & New York \\
\hline F. virguliforme & NRRL22825 & Glycine max & New York \\
\hline Monilinia fructicola & DB15 & Prunus persica & New York \\
\hline M. fructicola & DB27 & P. persica & New York \\
\hline Nectria borneensis & NRRL22579 & NA & Indonesia \\
\hline N. plagianthi & NRRL22632 & Hoheria galbrata & New Zealand \\
\hline Oidium neolycopersici & 06115 & S. lycopersicum & Maine \\
\hline Sclerotinia sclerotiorum & 04113 & C. аппиит & New York \\
\hline Septoria lycopersici & 06150 & S. lycopersicum & New York \\
\hline S. lycopersici & 0599 & S. lycopersicum & New York \\
\hline Stemphylium solani & ATCC 11128 & S. lycopersicum & South Carolina \\
\hline Trichoderma harzianum & T-22, G. Harman & NA & United States \\
\hline Verticillium albo-atrum & $96-006$, D. Kalb & Medicago sativa & New York \\
\hline V. dahliae & I1027, A. Charkowski & Fraxinus sp. & Wisconsin \\
\hline Fungi, Basidiomycota & & & \\
\hline Ceratobasidium sp. & 06134-1 & C. аппиит & New York \\
\hline Rhizoctonia solani & NZ20060120, M. Ohkura & NA & New York \\
\hline Stramenopila, Oomycota & & & New York \\
\hline Phytophthora capsici & $0664-1$ & C. аппиит & New York \\
\hline P. erythroseptica & 05-15529, S. Jensen-Tracy & S. tuberosum & New York \\
\hline$P$. infestans & 0491 & S. lycopersicum & New York \\
\hline$P$. infestans & 06127 & S. tuberosum & New York \\
\hline P. nicotianae & ATCC52638 & Cornus florida & Florida \\
\hline Pythium aphanidermatum & 0507 & Capsicum аппиит & New York \\
\hline P. aphanidermatum & Pa58.3, E. Nelson & Gypsophila sp. & Israel \\
\hline$P$. irregulare & 63108-98, G. Moorman & Schlumbergera sp. & NA \\
\hline P. ultimum & P4, E. Nelson & Phaseolus vulgaris & New York \\
\hline Protista, Plasmodiophorid & & & \\
\hline & & & \\
\hline f. sp. subterranea & 06125 & S. tuberosum & Wisconsin \\
\hline
\end{tabular}

${ }^{a}$ Target species of the macroarray are in bold and nontarget species used for specificity tests are in plain text. NA = data not available.

${ }^{\mathrm{b}}$ ATCC $=$ American Type Culture Collection (Manassas, VA), NRRL = Agricultural Research Service Culture Collection (NCAUR, Peoria, IL), and other isolates were obtained from individuals as indicated. Isolates without indication were isolated by the authors.

${ }^{\mathrm{c}}$ An additional $18 \mathrm{~F}$. solani isolates used in our preceding article (28) also were tested against this array.

and identified based on microscopic morphology and internal transcribed spacer (ITS) sequencing results of pure cultures (see protocols below). The second portion was frozen in $-80^{\circ} \mathrm{C}$ for future use, and the third was used for DNA extraction and macroarray detection. For samples with multiple diseased plant parts (leaves, stems and roots), each part was sampled separately and DNA was extracted independently.

DNA extraction, PCR, and sequencing. Genomic DNA was extracted from pathogen cultures (Table 1) and diseased plant samples using the UltraClean Soil DNA Isolation Kit (MoBio, CA) following the manufacturer's protocols. The extracted genomic DNA concentration ranged from 15 to $120 \mathrm{ng} / \mu \mathrm{l}$, with higher yields from pure cultures. DNA was diluted 8- to 10-fold prior to PCR amplification. The ITS region was amplified with the universal primers ITS5 and ITS4 (27). PCR was carried out with $1 \times$ ThermoPol reaction buffer (New England BioLabs, MA), $1 \mathrm{mM}$ dNTPs, $0.2 \mu \mathrm{M}$ each primer, 1 unit Taq DNA polymerase (New England BioLabs), and 1.5 to $15 \mathrm{ng}$ of genomic DNA in a 50- $\mu$ l reaction. The following PCR cycling conditions were used: $95^{\circ} \mathrm{C}$ for $5 \mathrm{~min} ; 35$ cycles of $95^{\circ} \mathrm{C}$ for $1 \mathrm{~min}$, $56^{\circ} \mathrm{C}$ for $1 \mathrm{~min}$, and $72^{\circ} \mathrm{C}$ for $1 \mathrm{~min}$; followed by $10 \mathrm{~min}$ at $72^{\circ} \mathrm{C}$. PCR products were purified according to the manufacturer's protocol using the QIAquick PCR Purification Kit (Qiagen, CA). The purified PCR products from pure cultures were sequenced with the primers ITS5 and ITS4 in order to confirm the identity of each microbe and to facilitate detector oligonucleotide design (Fig. 1).

Detector oligonucleotide design and array production. The ITS sequences of the pathogens listed in Table 1 were used in BLAST searches against all sequences in GenBank. Similar ITS sequences were downloaded and aligned with the target sequences by the CLUSTAL $\mathrm{X}$ program (22). The polymorphic sites were identified visually. Multiple target-specific oligonucleotides (detector oligos) were then designed based on the polymorphic sites. Based on the results of our previous study (28), in order to achieve uniform performance in array hybridization, the length of the designed oligomer should be between 17 and 27 nucleotides, and the estimated melting temperature $(\mathrm{Tm})$ range from 50 to $60^{\circ} \mathrm{C}$. The $\mathrm{Tm}$ was estimated using the following formula: $\mathrm{Tm}=64.9+41 \times(y+$ $z-16.4) /(w+x+y+z)$, where $w, y$, and $z$ are the number of the bases A, T, G, and C in the sequence, respectively (9). Sequences of the designed detector oligonucleotides were then used in BLAST searches against the entire GenBank database. Detector oligonucleotides that had identical or end mismatches with nontarget species were eliminated unless there was inadequate sequence variability between 
the target and nontarget species. In all, 21 oligonucleotides specific for 12 members in the Fusarium solani species complex that were validated in the preceding study (28) also were included on this macroarray.

Array production followed the protocol described previously (28). Briefly, $10 \mathrm{fmol}$ of each detector oligonucleotide was spotted onto Hybond $\mathrm{N}+$ nylon membranes (GE Healthcare, NJ) using a 96-pin replicator (model 250520; Nalge Nunc International Corp., IL) in quadruplicate. The quadruplicate spots were placed adjacent to one another in either an " $L$ " or and "inverted-L" pattern. Three types of controls also were spotted. First, the positive controls included two fungal and oomycete universal primers (ITS4 and ITS5), one fungal universal primer (ITS2), and two oligonucleotides homologous to solanaceous plant ITS sequences (Solan1 and Solan2) (Table 2). Second, four internal controls (ITS2_1 to ITS2_5) that differed from primer ITS2 at one or two bases also were included on the membrane (Table 2). Negative controls were sterile water and the spotting buffer (28). Spotted membranes were air dried for $10 \mathrm{~min}$ and then fixed by UV exposure at $240 \mathrm{~mJ} / \mathrm{cm}^{2}$. After incubation in a $0.5 \%$ sodium dodecyl sulfate solution at $60^{\circ} \mathrm{C}$ for an hour, membranes were rinsed in $100 \mathrm{mM}$ Tris $(\mathrm{pH}$ 8.0) for $5 \mathrm{~min}$, and kept moist at $4{ }^{\circ} \mathrm{C}$ until use.

Hybridization. The ITS amplicons from the microorganisms and the plant samples were labeled and hybridized using the Gene Images AlkPhos Direct Labeling and Detection System with CDP-Star (Amersham Biosciences, NJ) following previously optimized protocols (28). Briefly, for all samples, the array was prehybridized at $55^{\circ} \mathrm{C}$ for $15 \mathrm{~min}$ and hybridized with $100 \mathrm{ng}(10 \mu \mathrm{l}$ of $10 \mu \mathrm{g} / \mu \mathrm{l})$ of labeled ITS amplicon at $55^{\circ} \mathrm{C}$ for $2 \mathrm{~h}$. After two primary washes and two secondary washes, the detection reagent was added to the array to react for an hour, followed by 30 min of film exposure. Chemiluminescence was detected using Kodak Biomax Light film. Developed films were scanned by a Hewlett-Packard 5300C ScanJet and read with ImageJ 1.33u (National Institutes of Health, MD). The signal intensity for hybridization was measured as the average gray value for the quadruplicate spots for each detector oligonucleotide on the array after the background gray values were subtracted. Each experiment was conducted twice. Oligonucleotides that had weak signals or cross-hybridization with nontarget species were excluded from the final macroarray.

Array sensitivity tests. Two experiments were performed to determine the detection limit of the PCR-coupled macroarray method. In the first experiment, genomic DNA of Stemphylium solani (ATCC 11128) and F. sambucinum
(NRRL 13504) was serially diluted prior to a standard ITS PCR amplification. In the second, genomic DNA of the two isolates were individually mixed with tomato genomic DNA in a range of ratios, simulating a field sample where the fungus of interest would contribute 10,1 , and $0.1 \%$ of the total DNA. The total amount of DNA was kept at $10 \mathrm{ng}$ while the ratio of pathogen to plant DNA varied. Following ITS PCR, hybridization for both experiments was conducted as described above. When the concentration of the ITS PCR product was lower than $10 \mu \mathrm{g} / \mu \mathrm{l}$ due to high dilution of the DNA template, $10 \mu \mathrm{l}$ of purified ITS PCR product was used for hybridization and gel electrophoresis. The experiments were conducted twice.

\section{RESULTS}

Amplification of pathogen ITS. For the fungal and oomycete pure isolates, ITS amplicons were about 600 and $800 \mathrm{bp}$, respectively. For the diseased plant tissues, both host plant and pathogen ITS were amplified in many cases, showing two or more bands in gel electrophoresis. The host ITS amplicons were about $700 \mathrm{bp}$.

Detector oligonucleotide design and array development. Based on the CLUSTAL $X$ sequence alignments, an adequate level of ITS sequence variability among most of the target species was present for oligomer design. Additionally, variability within a species was present in many target fungi and oomycetes. For species with such variability, either oligonucleotides were designed at the conservative sites or multiple oligonucleotides
Target

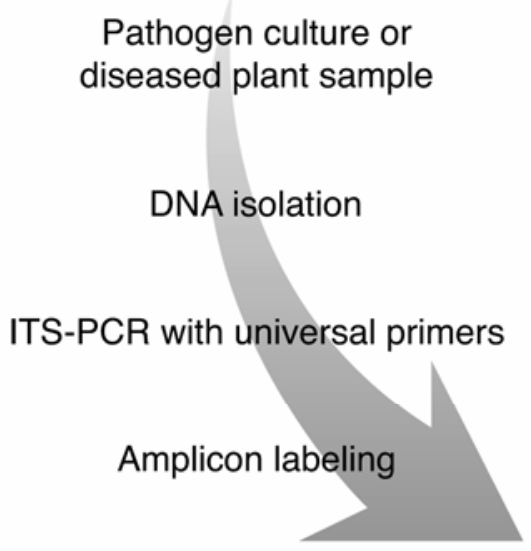

were designed to cover the polymorphisms within a species (Table 2). However, for 10 target pathogens, there was inadequate ITS sequence variability between them and certain nontarget species, most of which are not solanaceous pathogens (Table 2). Several versions of the array were tested against the target pathogens. The oligonucleotides that had cross-hybridization with nontarget species included in this study (Table 1) or showed no signal when hybridizing with the corresponding targets were eliminated. The final array, containing 105 oligos with the ability to detect and differentiate 25 fungal and oomycete pathogens plus 12 members of the $F$. solani species complex (28), was used for testing all the pure cultures (Table 1) as well as field samples (Table 3).

Array specificity. To ensure that detector oligonucleotides hybridized to the target species but did not cross-hybridize with nontarget species, the available pathogens (24 species) and their phylogenetically closely related species (16 species) were tested against the final array (Table 1). Except for members of the $F$. solani species complex, the other 23 target pathogens, for which we had either cultures or DNA (Table 1, species in bold), were unambiguously detected and differentiated by the macroarray without crosshybridization. The detector oligonucleotides included on the array were highly specific, and single nucleotide polymorphisms were clearly differentiated between closed related species. For example, oligonucleotide BOTR3 (GCTCGCCAGA GAATACEAAAACTCT) distinguished
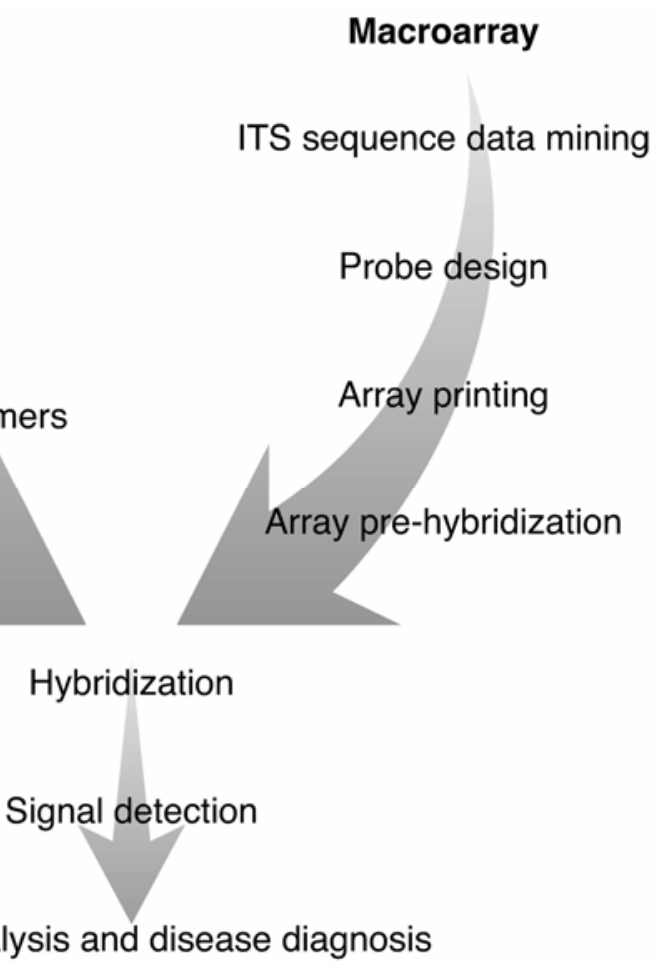

Fig. 1. Flowchart describing the process of macroarray development and detection of fungal and oomycete plant pathogens. 
Table 2. Tested detector oligonucleotides on the macroarray

\begin{tabular}{|c|c|c|c|c|}
\hline Target & $\begin{array}{l}\text { Oligo } \\
\text { name }\end{array}$ & Oligo sequence $5^{\prime}-3^{\prime}$ & Ref. $^{a}$ & Nontarget with sequence match ${ }^{b}$ \\
\hline Alternaria alternata & Aa1 & GCGGGCTGGAACCTCTCGG & $\ldots$ & A. longipes, A. tenuissima \\
\hline A. alternata & $\mathrm{Aa} 2$ & TTCGCCCACCACTAGGACAAAC & $\ldots$ & A. arborescens $A$. longipes, A. tenuissima \\
\hline A. alternata & Aa4 & GTCGCACTCTCTATCAGCAAAGGT & $\ldots$ & A. arborescens A. longipes, A. tenuissima \\
\hline A. solani & AsolR & ATGCTAGACCTTGGGGCTGGAA & 29 & $\begin{array}{l}\text { A. dauci, A. macrospora, A. porri, A. sesami, } \\
\text { A. tagetica, A. zinniae }\end{array}$ \\
\hline A. solani & As1 & CTCGCCCACCACAAGGACCAAC & $\ldots$ & A. daturicola, A. macrospora, A. tagetica, A. zinniae \\
\hline A. solani & As2 & CTCGCCCACCACAAGGACCAA & $\cdots$ & $\begin{array}{l}\text { A. dauci, A. macrospora, A. sesami, A. sesamicola, } \\
\text { A. zinniae }\end{array}$ \\
\hline A. solani & As 4 & TCGCGCTCTCTTCCAGCCCCA & $\cdots$ & $\begin{array}{l}\text { A. dauci, A. macrospora, A. porri, A. sesame, } \\
\text { A. tagetica, A. zinniae }\end{array}$ \\
\hline Botrytis spp. & BOTR1 & ССCTCAAGCTTAGCTTGGTATTGAG & $\ldots$ & $\ldots$ \\
\hline Botrytis spp. & BOTR2 & CTCAATACCAAGCTAAGCTTGAGGG & $\ldots$ & $\ldots$ \\
\hline Botrytis spp. & BOTR3 & GCTCGCCAGAGAATACCAAAACTCT & $\ldots$ & $\ldots$ \\
\hline Botrytis spp. & BOTR4 & AGAGTTTTGGTATTCTCTGGCGAGC & $\ldots$ & $\ldots$ \\
\hline Cladosporium fulvum & Cf1 & TCCAACCCTCTGTGAACCAACTC & $\ldots$ & C. colocasiae \\
\hline C. fulvum & $\mathrm{Cf} 2$ & CAACССТCTGTGAACCAACTCTG & $\ldots$ & C. colocasiae \\
\hline C. fulvum & Cf3 & CCCGGAGATCATCAAACACTGCA & $\ldots$ & C. colocasiae \\
\hline C. fulvum & $\mathrm{Cf} 4$ & CAGAGTTGGTTCACAGAGGGTTG & $\ldots$ & C. colocasiae \\
\hline C. fulvum & Cf5 & TGCAGTGTTTGATGATCTCCGGG & $\ldots$ & C. colocasiae \\
\hline Colletotrichum coccodes & Cc1NF1 & TGCCGCCTGCGGACCCCCCT & 5 & $\ldots$ \\
\hline C. coccodes & Cc1NF1R & AGGGGGGTCCGCAGGCGGCA & $\ldots$ & $\ldots$ \\
\hline C. coccodes & $\operatorname{Cc} 5$ & CCTGCCCTCACGGGCGGAGCGC & $\ldots$ & $\ldots$ \\
\hline C. coccodes & Cc6 & GCGCTCCGCCCGTGAGGGCAGG & $\ldots$ & $\ldots$ \\
\hline Colletotrichum spp. & $\mathrm{Cc} 2 \mathrm{R} 1$ & GTTAGGTATGTTCACAAAGGGTT & $\ldots$ & $\ldots$ \\
\hline Colletotrichum spp. & COLL1 & CGACGTTTCTTCTGAGTGGCACAAG & $\ldots$ & $\ldots$ \\
\hline Colletotrichum spp. & COLL2 & CTTGTGCCACTCAGAAGAAACGTCG & $\ldots$ & $\ldots$ \\
\hline Corynespora cassiicola & Coc1 & CCAACGGGGACCCACCACAAA & $\ldots$ & $\ldots$ \\
\hline C. cassiicola & $\operatorname{Coc} 2$ & TTTGTGGTGGGTCCCCGTTGG & $\ldots$ & $\ldots$ \\
\hline Fusarium oxysporum & Fox 2 & GTTGGGACTCGCGTTAATTCG & 13 & $\ldots$ \\
\hline F. oxysporum & Fo1 & CGTTCCTCAAATTGATTGGCGGTC & $\ldots$ & $\ldots$ \\
\hline F. oxysporum & Fo2 & CGTTCCTCAAATTGATTGGCGGTCA & $\ldots$ & $\ldots$ \\
\hline F. sambucinum & Fus2 & TTCCGAGGAACGGGCTGATCCG & $\ldots$ & F. tumidum \\
\hline F. sambucinum & Fus3 & AGCTGTCGTCTGACACTCCCCAAA & $\ldots$ & $\ldots$ \\
\hline F. sambucinum & Fus4 & TTTGGGGAGTGTCAGACGACAGCT & $\ldots$ & $\ldots$ \\
\hline F. solani & Fs2 & GAGGACTCTTAACTCTGTTTCTTA & 28 & $\ldots$ \\
\hline F. solani & Fs3 & CGCCGTAAAACACCCCAACTCTT & 28 & $\ldots$ \\
\hline F. solani & Fs4 & TCGCGTAGTAGCTAACACCTCGC & 28 & $\ldots$ \\
\hline F. solani & Fs5 & CGCCGTAAAACACCCAACTCTTCT & 28 & $\ldots$ \\
\hline F. solani & Fs6 & CCTGTGAACATACCTAAACGTTG & 28 & $\ldots$ \\
\hline F. solani & Fs7 & СCTAACTCTGTTGCTATATGTATC & 28 & $\ldots$ \\
\hline F. solani & Fs8 & ССTAATTCTGTTGCTATATGTATCTTC & 28 & $\ldots$ \\
\hline F. solani & Fs9 & TCTAACAACTCATCAACCCTGTGA & 28 & $\ldots$ \\
\hline F. solani & Fs13 & TTATACAACTCATCAACCCTGTGA & 28 & $\ldots$ \\
\hline F. solani & Fs 15 & GCAGCTTCCAATGCGTAGTAGCTA & 28 & $\ldots$ \\
\hline F. solani & Fs 17 & CGCCGTAAAACACCCAACTTTTAG & 28 & $\ldots$ \\
\hline F. solani & Fs18 & CCTGTGGGCACAACGCCGT & 28 & $\ldots$ \\
\hline F. solani & Fs19 & ACATACCTAAAACGTTGCCTCGG & 28 & $\ldots$ \\
\hline F. solani & Fs23 & CGCCGTAAAACCCCCAACTTCT & 28 & $\ldots$ \\
\hline F. solani & Fs24 & CCGCGGGCACACGCCGT & 28 & Leishmania braziliensis, Nectria plagianthi \\
\hline F. solani & Fs 25 & GCAGCTTCCATTGCGTAGTAGCCA & 28 & $\ldots$ \\
\hline F. solani & Fs26 & TTGCGTAGTAGCCAACACCTCGCA & 28 & $\ldots$ \\
\hline F. solani & Fs27 & CGCCGTGAAACACCCAACTTCT & 28 & $\ldots$ \\
\hline F. solani & Fs29 & ACTTACCTATAACGTTGCTTCGGC & 28 & $\ldots$ \\
\hline F. solani & Fs30 & CCGAGTCTAAACAACTCATCAAC & 28 & $\ldots$ \\
\hline F. solani & Fs31 & CCGAGTCTAAACAACTCATCAA & 28 & $\ldots$ \\
\hline Oidium neolycopersici & On2 & TTAAAGATAGTGGCGGTCCTGG & $\ldots$ & $\ldots$ \\
\hline O. neolycopersici & On3 & GGTGGGCGGCCGACACATGT & $\ldots$ & $\ldots$ \\
\hline Phoma destructiva & $\operatorname{Pd} 1$ & TTGTAGTTGCAATCAGCGTCTGACA & $\ldots$ & $\ldots$ \\
\hline P. destructiva & $\mathrm{Pd} 2$ & TGTCAGACGCTGATTGCAACTACAA & $\ldots$ & $\ldots$ \\
\hline P. destructiva & $\mathrm{Pd} 4$ & GTTTTTGTCAGACGCTGATTGCAAC & $\ldots$ & $\ldots$ \\
\hline Rhizoctonia solani & Rs2 & CAGTGTTATGCTTGGTTCCACTC & $\ldots$ & $\ldots$ \\
\hline R. solani & Rs3 & TGTTGAAACTTAGTATTAGATGCGT & $\ldots$ & $\ldots$ \\
\hline R. solani & Rs4 & GAGTGGAACCAAGCATAACACTG & $\ldots$ & $\ldots$ \\
\hline Sclerotinia sclerotiorum & SSFWD & GCTGCTCTTCGGGGCCTTGTATGC & 8 & S. minor, S. trifoliorum \\
\hline S. sclerotiorum & Ss 1 & GCTGCTCTTCGGGGCCTTGTATG & $\ldots$ & S. minor, S. trifoliorum \\
\hline S. sclerotiorum & Ss2 & GCATACAAGGCCCCGAAGAGCAGC & $\ldots$ & S. minor, S. trifoliorum \\
\hline S. sclerotiorum & Ss3 & CATACAAGGCCCCGAAGAGCAGC & $\ldots$ & S. minor, S. trifoliorum \\
\hline Septoria lycopersici & S11 & CCGGAGACCTTCAAACACTGCATCTT & $\ldots$ & S. lamiicola, S. senecionis \\
\hline S. lycopersici & $\mathrm{S} 12$ & CCGGAGACCTTCAAACACTGCATC & $\ldots$ & S. lamiicola, S. senecionis \\
\hline S. lycopersici & $\mathrm{S} 13$ & CCCGGAGACCTTCAAACACTGCAT & $\ldots$ & S. lamiicola, S. senecionis \\
\hline
\end{tabular}

\footnotetext{
${ }^{a}$ Reference numbers for literature citations. Detector oligonucleotides that do not have a reference were designed by the authors for this study.

${ }^{b}$ Nontarget species that have an identical sequence based on a BLAST search of GenBank.

${ }^{\mathrm{c}}$ ITS $=$ internal transcribed spacer.
} 
Table 2. (continued from preceding page)

\begin{tabular}{|c|c|c|c|c|}
\hline Target & $\begin{array}{l}\text { Oligo } \\
\text { name }\end{array}$ & Oligo sequence $5^{\prime}-3^{\prime}$ & Ref. $^{a}$ & Nontarget with sequence match \\
\hline Stemphylium solani & STs1 & TGGGCGTCTTTTGTCTCTCACGAG & $\ldots$ & Pleospora tarda, S. trifolii \\
\hline S. solani & STs2 & ACTTCGGTGCGGGCTCCAGCTT & $\ldots$ & S. lancipes \\
\hline S. solani & STs3 & CTCGTGAGAGACAAAAGACGCCCA & $\ldots$ & P. tarda, S. trifolii \\
\hline S. solani & STs4 & AAGCTGGAGCCCGCACCGAAGT & $\cdots$ & S. lancipes \\
\hline Verticillium albo-atrum & Val1 & GCCGGTACATCAGTCTCTTTATTCA & 13 & $\ldots$ \\
\hline V. albo-atrum & Va5 & GCCGGTACATCAGTCTCTTTATTCAT & $\ldots$ & $\ldots$ \\
\hline V. dahliae & $\mathrm{Vda} 2$ & GTCCATCAGTCTCTCTGTTTAT & 13 & $\ldots$ \\
\hline V. dahliae & Vd1 & CGGTCCATCAGTCTCTCTGTTTAT & $\ldots$ & $\ldots$ \\
\hline V. dahliae & $\mathrm{Vd} 2$ & CCGGTCCATCAGTCTCTCTGTTTA & $\ldots$ & $\ldots$ \\
\hline V. dahliae & $\mathrm{Vd} 3$ & TAAACAGAGAGACTGATGGACCGG & $\ldots$ & $\ldots$ \\
\hline Phytophthora capsici & Pc1 & TTTAGTTGGGGGTCTTGTACCC & $\ldots$ & P. tropicalis \\
\hline P. capsici & Pc2 & TGTTGTCCTTCGGGTCGACTG & $\ldots$ & P. glovera \\
\hline P. capsici & Pc3 & GTGTTGTCCTTCGGGTCGACTG & $\ldots$ & P. glovera \\
\hline P. capsici & $\mathrm{Pc} 4$ & CGGCGTTTAAAGGAGGAGTGTTC & $\ldots$ & $\ldots$ \\
\hline P. capsici & Pc6 & CAGGCGCTTATTGAATGCTTTTCC & $\ldots$ & P. glovera \\
\hline P. erythroseptica & Pe1 & AGTAGGGTGTCTGTTCCGGCGTAA & $\ldots$ & $\ldots$ \\
\hline P. erythroseptica & $\mathrm{Pe} 2$ & TTACGCCGGAACAGACACCCTACT & $\ldots$ & $\ldots$ \\
\hline P. erythroseptica & Pe3 & GGTGTCTGTTCCGGCGTAAGCT & $\ldots$ & $\ldots$ \\
\hline P. erythroseptica & $\mathrm{Pe} 4$ & AGCTTACGCCGGAACAGACACC & $\ldots$ & .. \\
\hline P. infestans & Pi1 & TGGGCGAGCCCTATCAAAAGG & $\ldots$ & P. andina, $P$. ipomoeae, $P$. mirabilis, $P$. phaseoli \\
\hline P. infestans & $\mathrm{Pi} 2$ & ACCATGGCTCTTTAGCTTGGCAT & $\ldots$ & $P$. andina, $P$. ipomoeae, $P$. mirabilis, $P$. phaseoli \\
\hline$P$. infestans & $\mathrm{Pi3}$ & CCATGGCTCTTTAGCTTGGCAT & $\ldots$ & $P$. andina, $P$. ipomoeae, $P$. mirabilis, $P$. phaseoli \\
\hline P. nicotianae & Pn1 & TGTGAAGGCTGCTATTGGGGCAAATT & $\ldots$ & $\ldots$ \\
\hline P. nicotianae & Pn2 & GTGAAGGCTGCTATTGGGGCAAATT & $\ldots$ & $\ldots$ \\
\hline Pythium aphanidermatum & $\mathrm{Pa} 1$ & GGAGAGAGATGGCAGAATGTGAG & $\ldots$ & P. deliense, $P$. myriotylum \\
\hline P. aphanidermatum & $\mathrm{Pa} 2$ & GGGAGAGAGATGGCAGAATGTGAG & $\ldots$ & $P$. deliense, $P$. myriotylum \\
\hline P. aphanidermatum & $\mathrm{Pa} 3$ & GAGGTGTACCTGAATTGTGTGAGG & $\ldots$ & $P$. deliense, $P$. myriotylum \\
\hline P. aphanidermatum & $\mathrm{Pa} 4$ & CGACGTTGCAGCTGACAGAGTGT & $\ldots$ & $P$. deliense, $P$. myriotylum \\
\hline P. aphanidermatum & $\mathrm{Pa} 5$ & TGATTCTCGAATCGCGGTGATCTG & $\ldots$ & P. myriotylum \\
\hline P. irregulare & Pyi1 & CGAGTGTGTGTGTTGTCGGTGC & $\ldots$ & $\ldots$ \\
\hline P. irregulare & Pyi2 & GCACCGACAACACACACACTCG & $\ldots$ & $\ldots$ \\
\hline P. irregulare & Pyi3 & GTGCTGTTGCATGCGCGGCTGA & $\ldots$ & $\ldots$ \\
\hline P. ultimum & Pul1 & TGCTGACTCCCGTTCCAGTG & 17 & P. debaryanum \\
\hline P. ultimum & Pul & CGATGTATGGAGACGCTGCATTT & $\ldots$ & P. debaryanum \\
\hline P. ultimum & Pu3 & AAATGCAGCGTCTCCATACATCG & $\ldots$ & P. debaryanum \\
\hline \multicolumn{5}{|l|}{ Spongospora subterranea } \\
\hline f. sp. subterranea & Sps 1 & GGCTAGCTCGAAACCTTATGCAAA & $\ldots$ & $\ldots$ \\
\hline S. subterranea f. sp. subterranea & Sps 2 & TTTGCATAAGGTTTCGAGCTAGCC & $\ldots$ & $\ldots$ \\
\hline S. subterranea f. sp. subterranea & Sps5 & GATATCCTTGAAAGCATGCCTCTTTG & $\ldots$ & S. subterranea f. sp. nasturtii \\
\hline Fungi & ITS4 & TCCTCCGCTTATTGATATGC & 27 & $\ldots$ \\
\hline Fungi & ITS5 & GGAAGTAAAAGTCGTAACAAGG & 27 & $\ldots$ \\
\hline Fungi & ITS2 & GCTGCGTTCTTCATCGATGC & 27 & $\ldots$ \\
\hline ITS2 C-G central mismatch ${ }^{\mathrm{c}}$ & ITS2_1_1 & GCTGCGTTGTTCATCGATGC & 28 & $\ldots$ \\
\hline ITS2 T-A central mismtach & ITS2_1_2 & GCTGCGTTCATCATCGATGC & 28 & $\ldots$ \\
\hline ITS2 G-C end mismatch & ITS2_1_3 & CCTGCGTTCTTCATCGATGC & 28 & $\ldots$ \\
\hline ITS2 CT-GA central mismatch & ITS2_2_1 & GCTGCGTTGATCATCGATGC & 28 & $\ldots$ \\
\hline ITS2 GC-CG end mismatch & ITS2_2_2 & CGTGCGTTCTTCATCGATGC & 28 & $\ldots$ \\
\hline Solanaceae & Solan1 & ACGTCGCGGCAAGTGGTGGTT & $\ldots$ & $\ldots$ \\
\hline Solanaceae & Solan2 & AACCACCACTTGCCGCGACGT & $\ldots$ & $\ldots$ \\
\hline
\end{tabular}

Botrytis cinerea from Sclerotinia sclerotiorum, whose sequence is only one base pair different at the homologous site (GCT CGCCAGAGAATATCAAAACTCT). The positive controls for fungi and oomycetes also produced signals as expected. The internal controls with one or two mismatched nucleotides did not produce a signal or had very weak signals and were used as a threshold when scoring hybridization results. Spots that had gray values higher than those of the internal controls were recorded as positive (28).

This macroarray also included 21 validated $F$. solani oligonucleotides from our preceding array that could differentiate 12 members of the $F$. solani complex (Table 2) (28). The F. solani oligonucleotides performed the same way in this array as in the previous $F$. solani species complex array, therefore further supporting the re- peatability of the detection system. As in the previous study, we again found that 2 of the $21 \mathrm{~F}$. solani oligonucleotides crosshybridized with four closely related nontarget species. Fs 4 cross-hybridized with $F$. cuneirostrum, F. illudens, F. virguliforme, and Nectria plagianthi; and Fs24 crosshybridized with F. illudens and N. plagianthi (28). The cross-hybridizing nontarget species can be distinguished easily because they only hybridized with Fs4 or Fs24. Therefore, their array patterns are different from the target $F$. solani species, which hybridized with the other $19 \mathrm{~F}$. solani oligonucleotides and formed unique array patterns. There was no other crosshybridization between any of the 16 nontarget species and the other target-specific detector oligonucleotides on the array.

Field and greenhouse samples. Two or more pathogens were detected from 23 of the 46 field and greenhouse samples (Table 3). Host DNA also was detected from many samples. In all cases, the array hybridization results of a pure culture isolated from a field sample matched that of the field sample and, frequently, the field sample had additional hybridizing detector oligonucleotides due to the presence of host tissue (which frequently, but not always, hybridized to the Solanaceae detector oligonucleotides) or multiple pathogens. Figure 2 is an example of this, showing results from a pure culture of $P$. infestans and a field potato sample with late blight symptoms, which showed the late blight pathogen as well as Phoma destructiva, Alternaria alternata, and the host. In addition to pathogen detection from leaf tissue, root tissue also was used successfully. The tomato sample used in Figure 3 had symptoms of Fusarium wilt. 
When the ITS amplicons from root, stem, and leaf tissue of this sample were combined and hybridized with the array, the simultaneous detection of four fungal species was observed. F. solani, F. oxysporum, $P$. destructive, and A. alternata all were detected (Fig. 3). The array also worked well for potato tubers, because Spongospora subterranea f. sp. subterranea, A. alternata, and a Colletotrichum sp. were detected from a potato tuber sample with only powdery scab symptoms at the time of collection. Spores of Colletotrichum and Alternaria spp. were observed from the same sample after several days of moist-chamber incubation. The common secondary pathogen, $A$. alternata, was detected from 28 of the 46 field and greenhouse samples.

Array sensitivity tests. The detection limit of the macroarray was determined by two tests. In the first sensitivity test, the macroarray unambiguously detected as low as $0.04 \mathrm{pg}$ of genomic DNA for both Stemphylium solani (ATCC 11128) and $F$. sambucinum (NRRL 13504). At this low DNA level, the PCR amplicons were not visible by agarose gel electrophoresis (Fig. 4). In the second test, ITS amplicons of the two fungal isolates were individually combined with the tomato host DNA to simulate mixed DNA from a field sample. Both pathogens were clearly detected when they contributed only $0.1 \%$ of the total DNA (data not shown). The results of the sensitivity tests were reproducible.

\section{DISCUSSION}

The objective of this study was to develop a detection system for fungal and

Table 3. Pathogens detected by the macroarray from 46 field or greenhouse solanaceous plant samples

\begin{tabular}{|c|c|c|c|c|}
\hline Host (no.), sample name ${ }^{a}$ & $\begin{array}{l}\text { Plant part } \\
\text { sampled }\end{array}$ & Symptoms & $\begin{array}{c}\text { Pathogens identified } \\
\text { visually }\end{array}$ & $\begin{array}{l}\text { Pathogens identified } \\
\text { by array }\end{array}$ \\
\hline \multicolumn{5}{|l|}{ Solanum lycopersicum (23) } \\
\hline $04119-1$ & Leaf & Leaf spot & Alternaria alternata & A. alternata \\
\hline $04120-2$ & Leaf & Powdery mildew & Oidium neolycopersici & A. alternata, $O$. neolycopersici \\
\hline 04123 & Leaf & Leaf blight & A. alternata & A. alternata \\
\hline $04124-1$ & Leaf & Leaf spot & A. alternata, Septoria lycopersici & A. alternata, S. lycopersici \\
\hline $04124-2$ & Leaf & Leaf spot & S. lycopersici & A. alternata, S. lycopersici \\
\hline 04124-4 & Stem & White rot & Sclerotinia sclerotiorum & S. sclerotiorum \\
\hline 0562 & Leaf & Leaf spot & A. alternata, Septoria lycopersici & A. alternata, S. lycopersici \\
\hline 0574 & Leaf & Leaf spot & S. lycopersici & A. alternata, S. lycopersici \\
\hline 0595 & Fruit & Black lesion & A. alternata, Fusarium oxysporum & A. alternata, $F$. oxysporum \\
\hline $05102-1$ & Leaf & Late blight & A. alternata, Phytophthora infestans & A. alternata, $P$. infestans \\
\hline 05104 & Stem & White rot & Sclerotinia sclerotiorum & S. sclerotiorum \\
\hline 0612 & Leaf & Leaf mold & $\begin{array}{l}\text { A. alternata, } F \text {. oxysporum, } \\
\text { Phoma destructiva }\end{array}$ & A. alternata, $F$. oxysporum, $P$. destructiva \\
\hline 0614 & Leaf & leaf blight & A. alternata & A. alternata \\
\hline $0615 \mathrm{~A}$ & Fruit & rot & Botrytis sp. & Botrytis sp. \\
\hline 0626 & Leaf & Leaf spot & Septoria lycopersici & A. alternata, S. lycopersici \\
\hline 0628 & Leaf, root, stem & $\begin{array}{l}\text { Leaf browning, } \\
\text { stem discoloration }\end{array}$ & A. alternata, Fusarium sp. & $\begin{array}{l}\text { A. alternata, } F \text {. oxysporum, } F \text {. solani, } \\
P \text {. destructiva }\end{array}$ \\
\hline 0633A & Leaf & Leaf blight & A. alternata & A. alternata \\
\hline 06115 & Leaf & Powdery mildew & O. neolycopersici & A. alternata, $O$. neolycopersici \\
\hline 0728 & Leaf & Leaf mold & A. alternata, Cladosporium fulvum & A. alternata, $C$. fulvum \\
\hline CA109(G) & Root & No symptom & F. solani & F. solani \\
\hline CA113(G) & Root & No symptom & F. solani & F. solani \\
\hline BMP0182(G) & Leaf & Early blight & A. solani & A. solani \\
\hline $\operatorname{Pa} 58.3(\mathrm{G})$ & Stem & Damping off & Pythium aphanidermatum & P. aphanidermatum \\
\hline \multicolumn{5}{|l|}{ S. tuberosum (8) } \\
\hline 0644 & Leaf & Leaf blight & A. alternata, $F$. oxysporum & $\begin{array}{l}\text { A. alternata, Colletotrichum sp., } \\
\text { F. oxysporum }\end{array}$ \\
\hline 06108 & Root & Root rot & Fusarium spp. & A. alternata, $F$. oxysporum, $F$. solani \\
\hline 06125 & Tuber & Powdery scab & $\begin{array}{l}\text { A. alternata, Spongospora } \\
\text { subterranean f. sp. subterranean }\end{array}$ & $\begin{array}{l}\text { A. alternata, Colletotrichum sp., } \\
\text { S. subterranean f. sp. subterranean }\end{array}$ \\
\hline 06127 & Leaf & Late blight & A. alternata, Phytophthora infestans & $\begin{array}{l}\text { A. alternata, } P \text {. infestans, } \\
\text { Phoma destructiva }\end{array}$ \\
\hline 06135 & Stem & $\begin{array}{l}\text { Vascular tissue } \\
\text { discoloration }\end{array}$ & A. alternata, Verticillium dahliae & A. alternata, V. dahliae \\
\hline $06156-1$ & Stem & Stem rot & F. solani & F. solani \\
\hline NRRL13504 (G) & Tuber & Dry rot & F. sambucinum & F. sambucinum \\
\hline NZ20060120(G) & Tuber & Canker & Rhizoctonia solani & R. solani \\
\hline \multicolumn{5}{|l|}{ Capsicum annuum (13) } \\
\hline 0465 & Fruit & Gray mold & Botrytis sp. & Botrytis sp. \\
\hline 0466 & Fruit & Gray mold & Botrytis sp. & Botrytis sp. \\
\hline 04114 & Fruit & Fruit rot & Colletotrichum sp. & Colletotrichum coccodes \\
\hline $04121-1$ & Leaf & Leaf blight & A. alternata & A. alternata \\
\hline 0552 & Stem & Stem discoloration, rot & F. solani, Pythium sp. & F. solani, Pythium aphanidermatum \\
\hline $0585-1$ & Fruit & Anthracnose & A. alternata, Colletotrichum $\mathrm{sp}$. & A. alternata, Colletotrichum $\mathrm{sp}$. \\
\hline 0590 & Fruit & Black lesion & A. alternata & A. alternata \\
\hline 0596 & Fruit & Anthracnose & Colletotrichum sp. & Colletotrichum sp. \\
\hline 05103-1 & Leaf & Leaf rot & A. alternata, Phytophthora capsici & A. alternata, $P$. capsici \\
\hline 0627 & Stem & Stem rot & Fusarium spp. & $F$. oxysporum, $F$. solani \\
\hline 0635 & Flower & Rot & A. alternata & A. alternata, Phoma destructiva \\
\hline 0637 & Stem & Stem discoloration & A. alternata, $F$. oxysporum & A. alternata, $F$. oxysporum \\
\hline 0664 & Fruit & Fruit rot & Phytophthora capsici & P. capsici \\
\hline \multicolumn{5}{|l|}{ S. melongena (2) } \\
\hline 0495 & Fruit & Rot & A. alternata & A. alternata \\
\hline 0643B & Fruit & Browning & Phoma destructiva & P. destructiva \\
\hline
\end{tabular}

a Number in parenthesis = number of samples tested. Sample names followed by $(\mathrm{G})$ refer to the greenhouse samples inoculated with the corresponding pathogen isolates. 
oomycete pathogens of solanaceous crops. Currently, PCR and real-time PCR are the most commonly applied molecular tools in fungal and oomycete pathogen detection. Specific PCR primers have been developed for a number of important pathogens, including F. solani (root rot) (12), Rhizoctonia solani (damping-off) (12), Sclerotinia sclerotiorum (white mold) (8), Synchytrium endobioticum (potato wart disease) (26), Verticillium spp. (Verticillium wilt) (12,25), Phytophthora infestans (late blight) (23), Pythium ultimum (root rot and damping-off) (12), and others. These molecular techniques are fast and sensitive compared with the conventional diagnostic method based on phenotypic characteristics. However, the main drawback is that they can detect only one or a few pathogens at a time. Due to its remarkable multispecies detection capability, the macroarray technique was chosen to fulfill the purpose of this study. We have developed a macroarray that can detect 24 pathogens plus 12 members of the $F$. solani species complex, and have verified its utility using both pure isolates and diseased plant tissues.

One of the challenges of the array detection is oligonucleotide design. Although both macroarray and PCR detection utilize the same mechanism-the selective nature of DNA-DNA hybridization-it is not as simple as just spotting previously designed PCR or real-time PCR primers together on a membrane. The published sets of primers were designed separately and may have
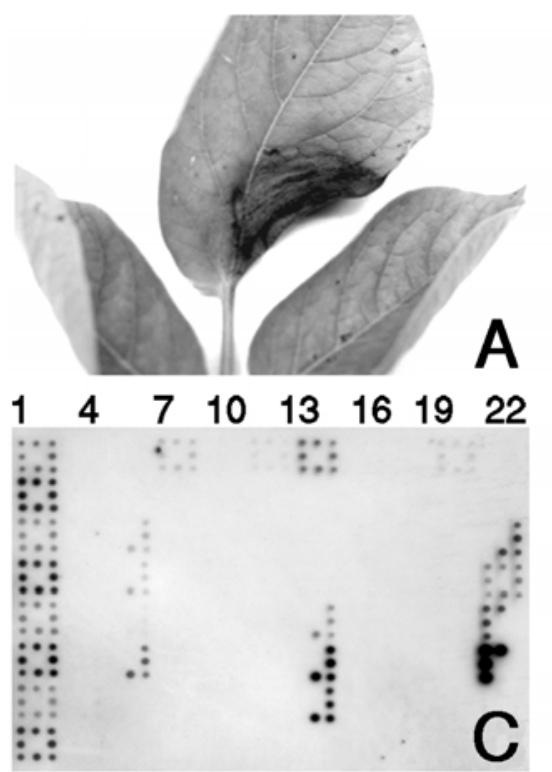

been designed for different regions of DNA or have different lengths and annealing temperatures and, therefore, require different hybridization conditions. Uniformity in length and annealing temperature, however, is essential for good performance of all oligonucleotides (14,24). To achieve this uniformity, many oligonucleotides were newly designed in this study based on ITS sequences. The lack of ITS sequence variability in some closely related taxa limited the oligonucleotide design. Therefore, certain oligonucleotides can only specify to genus level, such as the Botrytis oligonucleotides. In addition, 41 of the 105 oligonucelotides have sequences which match with nontarget species. These nontarget species are less likely to be present in the solanaceous hosts than the target pathogen. However, one should be careful when using the array to assess samples that contain a wide range of unknown microorganisms such as soil or water. An array using a more variable gene, such as translation elongation factor $1-\alpha$ gene, or using multiple genes could overcome this limitation and improve the specificity of the detection.

Achieving efficient pathogen DNA isolation and amplification from diseased plant tissue is another challenge. The optimized protocol described above was able to detect $0.04 \mathrm{pg}$ of fungal DNA, which is lower than the normal 0.3 to $10 \mathrm{pg}$ from other similar molecular detection studies $(13,19,26)$. The array was even able to
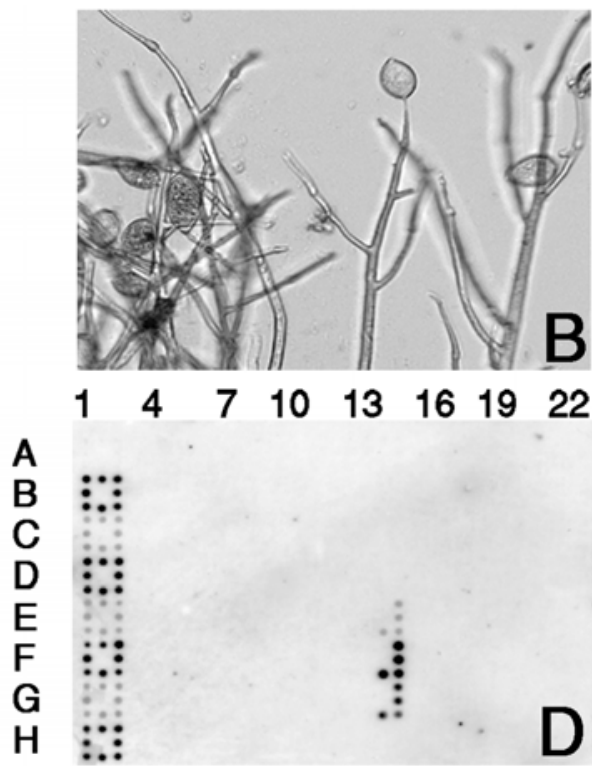

Fig. 2. Comparison of macroarray results between a pure culture of Phytophthora infestans and a lateblight-diseased field sample. A, Late blight symptoms on a potato leaflet. B, P. infestans sporangia and sporangiophores from the leaf in A $(\times 40)$. C, Macroarray detection results from the sample shown in A, showing positive signals by specific detector oligonucleotides for P. infestans (E14, F14, and G14), and secondary pathogens Alternaria alternate (D21, E21, and F21) and Phoma destructiva (C6, D6, and F6). Other spots at the left and top boarders are positive controls (internal transcribed spacer [ITS]4-B1, -B2, -D1, -D2, -F1, -F2 -,H1, -H2; ITS5-C1, -C2, -E1, -E2, -G1, -G2; ITS2-A1, -A2, -A13, -A14) and internal controls (ITS2_1_1-A3, -A4, -A15, -A16; ITS2_1_2-A5, -A6, -A17, -A18; ITS2_1_3-A7, -A8, -A19, -A20; ITS2_2_1-A9, -A10, -A21, -A22; ITS2_2_2-A11, -A12, -A23, -A24). Positive signals from the plant-specific oligos can also be seen (C22, D22). D, Macroarray results for pure culture of $P$. infestans. detect target DNA when the PCR amplicons were not visible by gel electrophoresis, which indicates a higher sensitivity than the regular PCR detection method. The array sensitivity tests in this study used two representative target species and the detection limit results were identical. However, in such a large detection system, the detection limits still may vary among the detector oligonucleotides and among different target species. Attempts were made to mediate this problem by designing detector oligonucleotides that were as uniform as possible. As reported by Lievens et al. (14), the presence of nontarget DNA that also can be amplified by the target DNA primers can decrease array sensitivity. Therefore, the detection sensitivity may be further increased by using multiple primer pairs for PCR amplification, which are more specific to a particular target. This could be accomplished by using one primer pair for fungi, one pair for oomycetes, and another pair specific for the host plants.

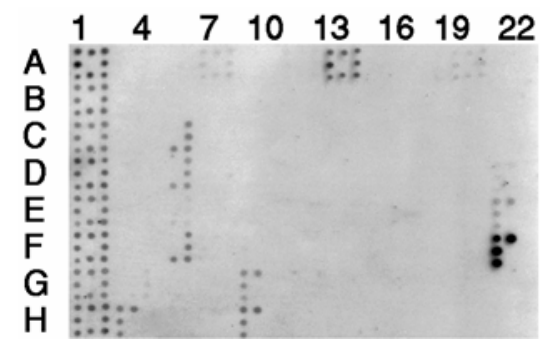

Fig. 3. Macroarray results of a tomato field sample with multiple pathogens. Macroarray detection results showing positive signals by specific detector oligonucleotides for Fusarium solani (H3), F. oxysporum (G9 and H9), Phoma destructiva (C6, D6, and F6), and Alternaria alternata (E21 and F21). Other spots on the array are controls identical to those in Figure 2.

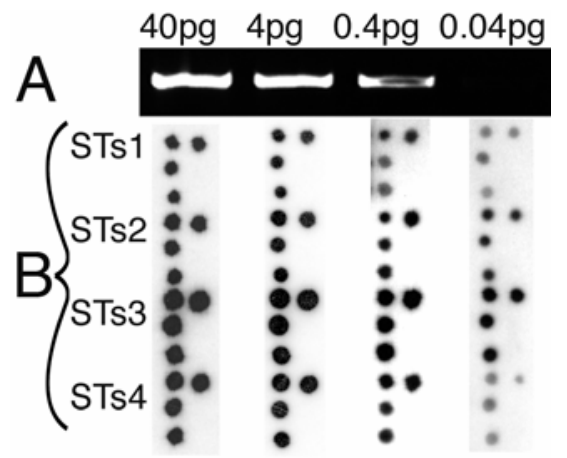

Fig. 4. Sensitivity test results of macroarray detection of Stemphylium solani (ATCC11128). A, Ethidium bromide-stained agarose gel of internal transcribed spacer-polymerase chain reaction (ITS-PCR) amplicons with the starting amount of pathogen DNA template used for PCR labeled above each well. Purified ITS PCR product $(10 \mu \mathrm{l})$ was loaded in each well. B, Hybridization signals produced by $S$. solanispecific detector oligonucleotides STs1-STs4 using the same amount of the corresponding amplicon from A. 
It was interesting, but perhaps not surprising, that the common fungus A. alternata was identified in 28 of the 46 field and greenhouse samples. As can be seen in Figures $2 \mathrm{C}$ and 3 , a very strong signal is produced with one of the A. alternata oligonucleotides (Aa4, location F21 on the array), whereas the oligonucleotide Aa1 at location D21 produces a much weaker signal. The reason for this difference in signal intensity is unknown; however, it may be due to the location of the detector oligonucleotide sequence within the target amplicon. A similar situation is observed with detector oligonucleotides Solan1 and Solan2, which should hybridize with the ITS amplicon from all solanaceous crops. Samples from potato consistently produced a strong signal from both Solan detector oligonucleotides (Fig. 2C, location C22 and D22), whereas samples from tomato, pepper, and eggplant were more variable and sometimes were negative (Fig. 3). This variability probably was due to the ability of the ITS4 and ITS5 fungal PCR primers to amplify the host ITS region. Although this variability was observed with host tissue, the microbe detector oligonucleotides were very consistent. That is, although some oligonucleotides consistently had stronger or weaker signal intensity (as observed with the A. alternata oligonucleotides), we never observed both positive and negative results for any pathogen pure culture or field sample even with repeated sampling and testing.

The macroarray described here detects all target microorganisms in a sample, some of which may be causing disease as well as others that may simply be present in the environmental sample. If using the array for diagnostics, it is important to remember that a host and pathogen can occur together for much of the year and it is only under certain environmental conditions that a disease outbreak is observed. Therefore, as with other DNAbased molecular detection techniques, the array detection results should be interpreted carefully for disease diagnostic purposes.

Compared with other diagnostic methods for solanaceous crops, the most distinctive advantage of this array is that it can detect multiple pathogens in a single assay. In addition, the detection system utilizes inexpensive reagents, such as an unmodified oligonucleotide and standard Taq DNA polymerase, to be cost efficient. We can reliably wash and reuse a single array more than 10 times, and have stored membranes at $4^{\circ} \mathrm{C}$ for more than 1 year. Moreover, the array was tested heavily with a number of field and greenhouse samples and was proved to be accurate, sensitive, and highly repeatable. Macroarrays also have been shown to be semiquantitative because hybridization signals are proportional to the amount of DNA hybridized (14). Therefore, the oligonucleotide macroarray developed in this study has great potential in agricultural practice.

\section{ACKNOWLEDGMENTS}

The project was supported by the National Research Initiative of the United States Department of Agriculture Cooperative State Research, Education and Extension Service, grant number 2004-3560514325 , and by a grant from the office of the provost of Hobart and William Smith Colleges. We thank A. Charkowski, D. Geiser, S. Jensen-Tracey, J. Juba, D. Kalb, G. Moorman, E. Nelson, K. O'Donnell, M. Ohkura, B. Pryor, L. Smith, C. Stiles, and T. Zitter for providing fungal cultures (APHIS permit numbers P526P-06-01976 and P526P-07-03639) or DNA; H. Lange for technical assistance; and T. Glover (Hobart and William Smith Colleges) for advice.

\section{LITERATURE CITED}

1. Agindotan, B., and Perry, K. L. 2007. Macroarray detection of plant RNA viruses using randomly primed and amplified complementary DNAs from infected plants. Phytopathology 97:119-127.

2. Atkins, S. D., and Clark, I. M. 2004. Fungal molecular diagnostics: a mini review. J. Appl. Genet. 45:3-15.

3. Bodrossy, L., and Sessitsch, A. 2004. Oligonucleotide microarrays in microbial diagnostics. Curr. Opin. Microbiol. 7:245-254.

4. Caten, C. E., and Jinks, J. L. 1968. Spontaneous variability of single isolates of Phytophthora infestans. I. Cultural variation. Can. J. Bot. 46:329-348.

5. Cullen, D. W., Lees, A. K., Toth, I. K., and Duncan, J. M. 2002. Detection of Colletotrichum coccodes from soil and potato tubers by conventional and quantitative real-time PCR. Plant Pathol. 51:281-292.

6. Eom, H. S., Hwang, B. H., Kim, D. H., Lee, I. B., Kim, Y. H., and Cha, H. J. 2007. Multiple detection of food-borne pathogenic bacteria using a novel 16S rDNA-based oligonucleotide signature chip. Biosens. Bioelectron. 22:845853.

7. Fessehaie, A., De Boer, S. H., and Lévesque, C. A. 2003. An oligonucleotide array for the identification and differentiation of bacteria pathogenic on potato. Phytopathology 93:262269.

8. Freeman, J., Ward, E., Calderon, C., and McCartney, A. 2002. A polymerase chain reaction (PCR) assay for the detection of inoculum of Sclerotinia sclerotiorum. Eur. J. Plant Pathol. 108:877-886.

9. Howley, P. M., Israel, M. A., Law, M. F., and Martin, M. A. 1979. Rapid method for detecting and mapping homology between heterologous DNAs-evaluation of polyomavirus genomes. J. Biol. Chem. 254:4876-4883.

10. Jones, J. B., Jones, J. P., Stall, R. E., and Zitter, T. A., eds. 1991. Compendium of Tomato Diseases. The American Phytopathological Society, St. Paul, MN.

11. Kawasaki, E., Saiki, R., and Erlich, H. 1993. Genetic-analysis using polymerase chain reaction-amplified DNA and immobilized oligonucleotide probes-reverse dot-blot typing. Methods Enzymol. 218:369-381.

12. Lievens, B., Brouwer, M., Vanachter, A. C. R. C., Cammue, B. P. A., and Thomma, B. P. H. J. 2006. Real-time PCR for detection and quantification of fungal and oomycete tomato pathogens in plant and soil samples. Plant Sci. 171:155-165.

13. Lievens, B., Brouwer, M., Vanachter, A. C. R. C., Lévesque, C. A., Cammue, B. P. A., and Thomma, B. P. H. J. 2003. Design and development of a DNA array for rapid detection and identification of multiple tomato vascular wilt pathogens. FEMS Microbiol. Lett. 223:113-122.

14. Lievens, B., Brouwer, M., Vanachter, A. C. R.
C., Lévesque, C. A., Cammue, B. P. A., and Thomma, B. P. H. J. 2005. Quantitative assessment of phytopathogenic fungi in various substrates using a DNA macroarray. Environ. Microbiol. 7:1698-1710.

15. Lievens, B., Claes, L., Vanachter, A. C. R. C. Cammue, B. P. A., and Thomma, B. P. H. J. 2006. Detecting single nucleotide polymorphisms using DNA arrays for plant pathogen diagnosis. FEMS Microbiol. Lett. 255:129-139.

16. Lievens, B., and Thomma, B. P. H. J. 2005. Recent developments in pathogen detection arrays: Implications for fungal plant pathogens and use in practice. Phytopathology 95:13741380.

17. Saiki, R. K., Walsh, P. S., Levenson, C. H., and Erlich, H. A. 1989. Genetic-analysis of amplified DNA with immobilized sequence-specific oligonucleotide probes. Proc. Natl. Acad. Sci. USA 86:6230-6234.

18. Sholberg, P., O'Gorman, D., Bedford, K., and Lévesque, C. A. 2005. Development of a DNA macroarray for detection and monitoring of economically important apple diseases. Plant Dis. 89:1143-1150.

19. Silvar, C., Duncan, J. M., Cooke, D. E. L. Williams, N. A., Diaz, J., and Merino, F. 2005. Development of specific PCR primers for identification and detection of Phytophthora capsici Leon. Eur. J. Plant Pathol. 112:43-52.

20. Stevenson, W. R., Loria, R., Franc, G. D., and Weingartner, D. P., eds. 2001. Compendium of Potato Diseases, 2nd ed. The American Phytopathological Society, St. Paul, MN.

21. Tambong, J. T., De Cock, A. W. A. M., Tinker, N. A., and Lévesque, C. A. 2006. Oligonucleotide array for identification and detection of Pythium species (vol. 72, pg. 2691, 2006). Appl. Environ. Microbiol. 72:7429-7429.

22. Thompson, J. D., Gibson, T. J., and Higgins, D. G. 1997. The CLUSTAL-X windows interface: flexible strategies for multiple sequence alignment aided by quality analysis tools. $\mathrm{Nu}$ cleic Acids Res. 25:4876-4882.

23. Trout, C. L., Ristaino, J. B., Madritch, M., and Wangsomboondee, T. 1997. Rapid detection of Phytophthora infestans in late blight-infected potato and tomato using PCR. Plant Dis. 81:1042-1048.

24. Tsang, S., Sun, Z. H., Stewart, C., Lum, N., Frankenberger, C., Subleski, M., Rasmussen, L., and Munroe, D. J. 2004. Development of multiplex DNA electronic microarrays using a universal adaptor system for detection of single nucleotide polymorphisms. Biotechniques 36:682-688.

25. Usami, T., Abiko, M., Shishido, M., and Amemlya, Y. 2002. Specific detection of tomato pathotype of Verticillium dahliae by PCR assays. J. Gen. Plant Pathol. 68:134-140.

26. Van Den Boogert, P. H. J. F., Van Gent-Pelzer, M. P. E., Bonants, P. J. M., De Boer, S. H., Wander, J. G. N., Lévesque, C. A., Van Leeuwen, G. C. M., and Baayen, R. P. 2005. Development of PCR-based detection methods for the quarantine phytopathogen Synchytrium endobioticum, causal agent of potato wart disease. Eur. J. Plant Pathol. 113:47-57.

27. White, T. J., Bruns, T., Lee, S., and Taylor, J. 1990. Amplification and direct sequencing of fungal ribosomal RNA genes for Phylogenetics. In: PCR Protocols: A Guide to Methods and Applications. M. A. Innis, D. H. Gelfand, J. J. Sninsky, and T. J. White, eds. Academic Press, New York.

28. Zhang, N., Geiser, D. M., and Smart, C. D. 2007. Macroarray detection of solanaceous plant pathogens in the Fusarium solani species complex. Plant Dis. 91:1612-1620.

29. Zur, G., Shimoni, E., Hallerman, E., and Kashi, Y. 2002. Detection of Alternaria fungal contamination in cereal grains by a polymerase chain reaction-based assay. J. Food Prot. 65:1433-1440. 